Fate, Providence and Moral Responsibility in Ancient, Medieval and Early Modern Thought. Studies in Honour of Carlos Steel

Edited by: Pieter d'Hoine \& Gerd Van Riel

Contributors: Lambros Couloubaritsis (Université Libre de Bruxelles), Pierre Destrée (FNRS/Université Catholique de Louvain), Sylvain Delcomminette (Université Libre de Bruxelles), John Dudley (KU Leuven), Jörn Müller (Universität Würzburg), Frans De Haas (Leiden University), Keimpe Algra (Utrecht University), Jan Opsomer (KU Leuven), Luc Brisson (CNRS, UPR 76, Paris), Riccardo Chiaradonna (Università di Roma Tre), Alessandro Linguiti (Università di Siena), John Dillon (Trinity College Dublin), Bert van den Berg (Leiden University), Christoph Helmig (Universität zu Köln), Antonio L.C. Vargas (Humboldt Universität Berlin), Danielle A. Layne (Georgia Southern University), Alain Lernould (CNRS, Lille III), Geert Roskam (KU Leuven), Gary Gabor (Hamline University), Claudio Moreschini (Università di Pisa), Caroline Macé (KU Leuven), Michele Trizio (Università degli Studi di Bari Aldo Moro), Peter Van Deun (KU Leuven), Erika Gielen (KU Leuven), Daniel De Smet (CNRS, UMR 8584, Paris), Jules Janssens (KU Leuven), Richard Taylor (Marquette University), Wu Tianyue (Beijing University), Valérie Cordonier (CNRS, Laboratoire SPHERE, UMR 7217), Andreas Speer (Universität zu Köln), Rudi Te Velde (Tilburg University), Pasquale Porro (Università degli Studi di Bari Aldo Moro), Marialucrezia Leone (KU Leuven), Gordon Wilson (University of North Carolina, Asheville), Jean-Michel Counet (Université Catholique de Louvain), Kent Emery, jr (University of Notre Dame), Demmy Verbeke (KU Leuven), Filips Defoort (KU Leuven), and Guy Guldentops (Thomas Institut, Köln)

(C) 2014 by Leuven University Press / Presses Universitaires de Louvain / Universitaire Pers Leuven, Minderbroedersstraat 4, B-3000 Leuven (Belgium)

ISBN 9789058679703

$\mathrm{D} / 2014$ / 1869 / 15

Distributed by Leuven University Press http://upers.kuleuven.be/nl/book/9789058679703

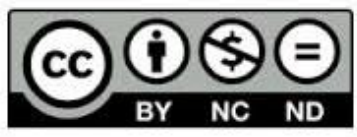

This work is licensed under a Creative Commons Attribution-NonCommercial-NoDerivs 3.0 Unported License: http://creativecommons.org/licenses/by-nc-nd/3.0/ 
FATE, PROVIDENCE AND MORAL RESPONSIBILITY

IN ANCIENT, MEDIEVAL AND EARLY MODERN THOUGHT 


\title{
ANCIENT AND MEDIEVAL PHILOSOPHY
}

\author{
DE WULF-MANSION CENTRE \\ Series I
}

XLIX

\author{
Series Editors \\ Russell L. Friedman \\ Jan Opsomer \\ Carlos Steel \\ Gerd Van Riel
}

\begin{abstract}
Advisory Board
Brad Inwood, University of Toronto, Canada Jill Kraye, The Warburg Institute, London, United Kingdom John Marenbon, University of Cambridge, United Kingdom Lodi Nauta, University of Groningen, The Netherlands Timothy Noone, The Catholic University of America, USA Robert Pasnau, University of Colorado at Boulder, USA

Martin Pickavé, University of Toronto, Canada Pasquale Porro, Università degli Studi di Bari, Italy Geert Roskam, KU Leuven, Belgium
\end{abstract}

The "De Wulf-Mansion Centre" is a research centre for Ancient, Medieval, and Renaissance philosophy at the Institute of Philosophy of the KU Leuven, Kardinaal Mercierplein, 2, B-3000 Leuven (Belgium).

It hosts the international project "Aristoteles latinus" and publishes the "Opera omnia" of Henry of Ghent and the "Opera Philosophica et Theologica" of Francis of Marchia. 


\title{
FATE, PROVIDENCE AND MORAL RESPONSIBILITY IN ANCIENT, MEDIEVAL AND EARLY MODERN THOUGHT
}

\author{
Studies in Honour of Carlos Steel
}

Edited by

Pieter d'Hoine and Gerd Van Riel

LEUVEN UNIVERSITY PRESS 
Published with support of Universitaire Stichting van België

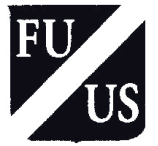

(C) 2014 by De Wulf-Mansioncentrum - De Wulf-Mansion Centre Leuven University Press / Presses Universitaires de Louvain / Universitaire Pers Leuven

Minderbroedersstraat 4, B-3000 Leuven (Belgium)

All rights reserved. Except in those cases expressly determined by law, no part of this publication may be multiplied, saved in an automated datafile or made public in any way whatsoever without the express prior written consent of the publishers.

ISBN 9789058679703

D / 2014 / 1869 / 15

NUR: 732 


\section{CONTENTS}

Gerd Van Riel (KU Leuven) \& Pieter d'Hoine (KU Leuven):

Fate, Providence and Moral Responsibility. An Introduction

1. Lambros Couloubaritsis (Université Libre de Bruxelles):

Émergence de la thématique de la providence divine de Diogène d'Apollonie à Platon

2. Pierre Destrée (FNRS/Université catholique de Louvain):

Comment être responsable de son destin? Platon et le mythe d'Er

3. Sylvain Delcomminette (Université Libre de Bruxelles):

Liberté et caractère dans le mythe d'Er

4. John Dudley (KU Leuven):

The Fate of Providence and Plato's World Soul in Aristotle

5. Jörn Müller (Universität Würzburg):

Was Aristotle an Ethical Determinist?

Reflections on His Theory of Action and Voluntariness

PART 2: HELLENISTIC AND EARLY IMPERIAL PHILOSOPHY

101

6. Frans A.J. de Haas (Leiden University):

Presuppositions of Moral Action in Aristotle and

Alexander of Aphrodisias

103

7. Keimpe Algra (Utrecht University):

Plutarch and the Stoic Theory of Providence

8. Jan Opsomer (KU Leuven):

The Middle Platonic Doctrine of Conditional Fate

9. Luc Brisson (CNRS, Paris/Villejuif):

The Question of Evil in the World in Plotinus 
10. Riccardo Chiaradonna (Università 'Roma Tre'):

Plotinus' Metaphorical Reading of the Timaeus: Soul, Mathematics,

Providence

11. Alessandro Linguiti (Università di Siena):

Choice, Self-Determination and Assimilation to God in Plotinus

PART 4: THE NEOPLATONIC COMMENTATORS

12. John Dillon (Trinity College Dublin):

Signs and Tokens: Do the Gods of Neoplatonism Really Care?

13. Robbert M. van den Berg (Leiden University):

A Problem concerning Providence: Proclus and Plutarch on Inherited Guilt and Postponed Punishment

14. Christoph Helmig (Universität zu Köln) \& Antonio L.C. Vargas (HU Berlin/Princeton):

Ascent of the Soul and Grades of Freedom. Neoplatonic Theurgy between Ritual and Philosophy

15. Danielle A. Layne (Georgia Southern University):

A Fatal or Providential Affair? Socrates and Alcibiades in Proclus'

Commentary on the Alcibiades I

16. Alain Lernould (CNRS, Lille III):

Le cycle triadique de la causalité démiurgique : Bonté, Vouloir, Providence. L'interprétation proclienne de Timée 29e1-30c2

17. Geert Roskam (KU Leuven):

Hermias of Alexandria on Socrates' Divine Sign

18. Gary Gabor (Hamline University):

When Should a Philosopher Consult Divination?

Epictetus and Simplicius on Fate and What Is Up to Us

PART 5: GREEK PATRISTICS AND THE BYZANTINE TRADITION

19. Claudio Moreschini (Università degli Studi di Pisa):

Goodness, Evil and the Free Will of Man in Gregory of Nyssa 
20. Caroline Macé (KU Leuven):

Édition d'un fragment Contre les astronomes, contenant une contribution à la théorie des quatre humeurs et des tempéraments

21. Michele Trizio (Università degli Studi di Bari Aldo Moro):

A Late Antique Debate on Matter-Evil Revisited in $11^{\text {th }}$-Century

Byzantium: John Italos and His Quaestio 92

22. Peter Van Deun (KU Leuven) \& Erika Gielen (KU Leuven):

The Metochion, Holy Sepulchre 363 Manuscript and an Unpublished Byzantine Opuscule on Predetermination

PART 6: THE ARABIC TRADITION

23. Daniel De Smet (CNRS, Paris):

La Providence selon le "Livre de la réprimande adressée de l'âme" attribué à Hermès Trismégiste. Un document néoplatonicien arabe oublié

24. Jules Janssens (KU Leuven):

What about Providence in the Best of All Possible Worlds?

Avicenna and Leibniz

25. Richard Taylor (Marquette University/KU Leuven):

Providence in Averroes

26. Tianyue Wu (Peking University):

Are First Movements Venial Sins? Augustinian Doctrine and Aquinas's Reinterpretation

27. Valérie Cordonier (CNRS, UMR 7219/Université Paris Diderot/

KU Leuven):

La doctrine aristotélicienne de la providence divine selon Thomas d'Aquin

28. Andreas Speer (Universität zu Köln):

Divine Government and Human Freedom

29. Rudi te Velde (Tilburg University):

Thomas Aquinas on Providence, Contingency and

the Usefulness of Prayer 
30. Pasquale Porro (Università degli Studi di Bari Aldo Moro/Université Paris-Sorbonne):

Divine Predestination, Human Merit and Moral Responsibility. The Reception of Augustine's Doctrine of Irresistible Grace in Thomas Aquinas, Henry of Ghent and John Duns Scotus

31. Marialucrezia Leone (Humboldt-Universität zu Berlin):

Henry of Ghent and the Ethics of Intention

32. Gordon Wilson (University of North Carolina, Asheville):

Henry of Ghent on Fatalism and Naturalism

33. Jean-Michel Counet (Université catholique de Louvain):

34. Kent Emery, jr (University of Notre Dame):

Fate, Providence and Predestination in the Sapiential Project of Denys the Carthusian

35. Demmy Verbeke (KU Leuven): Human Nature and Moral Responsibility in the Work of Juan Luis Vives 639

36. Guy Guldentops (Thomas Institut, Köln):

L'anti-fatalisme de Julius Sirenius

37. Filips Defoort (KU Leuven):

Jacob Boehme (1575-1624) on Predestination, Providence and Free Will

1. Index of Primary Sources 


\title{
HUMAN NATURE AND MORAL RESPONSIBILITY IN THE WORK OF JUAN LUIS VIVES
}

\author{
Demmy Verbeke
}

(KU Leuven)

\section{INTRODUCTION ${ }^{1}$}

In 1948, Ernst Cassirer, Paul Oskar Kristeller and John Randall, Jr. published what would become the most influential anthology of Renaissance philosophical texts in the English-speaking world. ${ }^{2}$ The title of their collection, The Renaissance Philosophy of Man, reveals the topic which has received most attention from scholars of Renaissance thought so far. This preoccupation is not justified by a presumed originality: studies have shown that fourteenth-, fifteenth- and sixteenth-century views on the misery of the human condition or the dignity of mankind for the most part repeat classical, biblical, patristic and medieval sources. ${ }^{3}$ However, it cannot be denied that the interest in the exploration of man's nature intensified during this period, with noteworthy results such as Poggio Bracciolini's De miseria humanae conditionis, Giannozzo Manetti's De dignitate et excellentia hominis and Aurelio Brandolini's De humanae vitae conditione (which presents both the positive and the negative view in dialogue form). This essay discusses the analysis of the human condition in the work of Juan Luis Vives (1492/3-1540), "one of the most prolific thinkers within the northern humanist tradition, a polymath with an intellect that in terms of depth and breadth is unmatched by the mind of any among his better-known contemporaries, ${ }^{\prime 4}$ who was also the only non-Italian thinker to be included in the aforementioned anthology.

${ }^{1}$ Unless otherwise indicated, all Latin texts of Vives in this essay are quoted (with slightly modernized spelling and punctuation) from Joannis Ludovici Vivis Valentini Opera omnia ... A Gregorio Majansio, 8 vols., Valentiae Edetanorum: in officina Benedicti Monfort, 1782-179o (henceforth: Mayans). I provide my own translation if no (satisfactory) modern one is available.

${ }^{2}$ E. Cassirer - P.O. Kristeller - J.H. Randall, Jr. (eds.), The Renaissance Philosophy of Man: Petrarca, Valla, Ficino, Pico, Pomponazzi, Vives, Chicago: University of Chicago Press, 1948.

${ }^{3}$ J. Kraye, 'Moral Philosophy', in: Ch. B. Schmitt - Q. Skinner - E. Kessler - J. Kraye (eds.), The Cambridge History of Renaissance Philosophy, Cambridge: Cambridge University Press, 1988, 301-386 (here 306-316).

4 J.A. Fernández-Santamaría, The Theater of Man: J.L. Vives on Society (Transactions of the American Philosophical Society; vol. 88/2), Philadelphia: American Philosophical Society, 1998, vii. 
After leaving his native Valencia in 1509, Juan Luis Vives studied in Paris, where he famously developed a distaste for the scholastic curriculum. ${ }^{5}$ Leaving Paris without a formal degree in the autumn of 1514, Vives moved to the Low Countries and divided his time between Bruges and Leuven, earning his livelihood as a private lecturer and enjoying the support of several noble patrons. This was followed by several stays in England, where he sought a position at the court and held a professorship at Corpus Christi College, Oxford. Siding with Queen Catherine during her divorce from Henry vin, Vives was eventually forced to leave the island permanently in 1528 . He moved back to the Low Countries, where he settled in Bruges (apart from a stint as private tutor of Doña Mencía de Mendoza in Breda), and wrote the treatises for which he is best known today: his De subventione pauperum on poor relief, an encyclopaedic work on education entitled De disciplinis and De anima et vita, which - at least according to Wilhelm Dilthey - marks the transition from metaphysical to descriptive and analytical psychology. ${ }^{6}$

Vives discussed the nature of man and his place in the world in several of his works, and his analysis of the human condition deserves a book-length study. The present contribution is less ambitious. Without claiming to be exhaustive, it focuses on the connection between Vives's philosophy of man and his diversified call for moral responsibility. The sources of his concept of man are wide-ranging: the following will reveal the influence of ancient philosophy and the Christian tradition. ? Vives's thought is thus marked by eclecticism, which is the result of his unwillingness to devote himself exclusively to one philosophical school, since he believed that no philosopher, no matter how great, had an exclusive right to the truth. Besides, according to Vives, non-critical admiration for predecessors blocks

5 The most recent and complete biography of Vives is E. González González, 'Juan Luis Vives. Works and Days', in: Ch. Fantazzi (ed.), A Companion to Juan Luis Vives (Brill's Companions to the Christian Tradition; 12), Leiden/Boston: Brill, 20o8, 15-64.

6 W. Dilthey, Weltanschauung und Analyse des Menschen seit Renaissance und Reformation (Wilhelm Dilthey, Gesammelte Schriften; 2), 1oth ed., Stuttgart: B.G. Teubner/ Göttingen: Vandenhoeck \& Ruprecht, 1977, 423-424. I owe this reference to L. Casini, 'Emotions in Renaissance Humanism: Juan Luis Vives' De Anima et Vita', in: H. Lagerlund - M. Yrjönsuuri (eds.), Emotions and Choice from Boethius to Descartes (Studies in the History of Philosophy of Mind; 1), Dordrecht: Kluwer, 2002, 205-228 (here 206). See also L. Casini, Cognitive and Moral Psychology in Renaissance Philosophy. A Study of Juan Luis Vives' De anima et vita, Uppsala: Universitetstryckeriet, 2006, 16.

7 C.G. Noreña, Juan Luis Vives (International Archives of the History of Ideas; 34), The Hague: Martinus Nijhoff, 1970, especially 148-175. That Vives's work was also influenced by medieval scholasticism is highlighted in L. Casini, 'Juan Luis Vives' Conception of Freedom of the Will and Its Scholastic Background', Vivarium 44, 2006, 396-417. 
intellectual progress, which should be based on accumulated experience rather than on a reliance on authoritative authors. ${ }^{8}$

\section{VIVES' CONCEPT OF MAN}

In one of his earliest works, the Fabula de homine, Vives provides the basic tenets of his concept of man. The short fable describes a banquet of the gods at which entertainment is provided by a sort of acting competition. Man is the last to perform and stuns all spectators, as he not only presents himself in his natural state (in other words: as a human being), but is also capable of transforming himself into a lower or a higher form, appearing on stage like a plant, various animals, the lower gods, and even as a likeness of Jupiter himself. Just as the famous Oratio of Giovanni Pico della Mirandola, Vives's Fabula thus celebrates the self-fashioning abilities of man..$^{9}$ This interpretation of human nature entails a great personal responsibility. It lies within our own will to become plants (devoid of sensations), animals (subjected to passions as anger, lust, or envy), humans (putting the common interest before our own, cf. infra), angels (surpassing human nature through the force of intellect), or even god-like (participating in immortality, wisdom, and prudence) ${ }^{10}$ It is therefore our own responsibility to choose which level of being

${ }^{8}$ Vives, De disciplinis vi 6, 36 ed. Mayans. See also B.P. Copenhaver - Ch.B. Schmitt, Renaissance Philosophy, paperback ed. (A History of Western Philosophy; 3), Oxford/New York: Oxford University Press, 2002, 202.

9 For the connection between Pico and Vives, see M.L. Colish, 'The Mime of God: Vives on the Nature of Man', Journal of the History of Ideas 23/1, 1962, 3-20; Ch. Fantazzi, 'Vives' Fabula de homine as a Dramatic Representation of Pico's Oratio', Nieuwsbrief Neolatinistenverband 15, 2003, 10-19 [Spanish version: 'La Fabula de homine como parodia de la oración de Pico de la Mirandola', in: F.J. Perez i Dura (ed.), La Universitat de València $i$ l'Humanisme: 'Studia Humanitatis' e renovació cultural a Europa i al Nou Món, València: Universidad de València, 2003, 79-87]; and E. De Bom, 'Homo ipse ludus ac fabula. Vives's Views on the Dignity of Man as Expressed in His Fabula de homine', Humanistica Lovaniensia 57, 2008, 91-114.

${ }^{10}$ Vives, Fabula de homine Iv 4-5 ed. Mayans: "Homo ipse, qui sub persona latet, sed emicans crebro, atque exiliens paene foras, et multis se in rebus clare ostendens, plane divinus Joveusque est, immortalitatis ipsius Jovis particeps, sapientiae, prudentiae, memoriae (...) namque is nonnumquam ita se se transformabat, ut sub persona plantae prodiret, agens unam vitam absque ullo sensu; paullum cum se abdidisset, in scenam regrediebatur Ethologus et Ethopaeus, deformatus in mille species belluarum: leonem diceres iratum et furentem, rapacem voracemque lupum, saevum aprum, astutulam vulpeculam, voluptuosam sordidamque suem, timidum leporem, invidum canem, stolidum asinum (...) Non expectabant dii eum pluribus visum iri formis, cum esse adest repente in eorum speciem reformatus, supra hominis ingenium, totus innixus sapientissimae menti." 
we aspire to, but it is clear that Vives believes that it is God's plan for man to at least transcend the vegetable and animal level.

In his later works, Vives specifies two related paths which are essential to develop our humanity: education and action. ${ }^{11}$ The basic assumption is that man is made - not born - human, and that education is therefore an important factor in realising our full potential as human beings. ${ }^{12}$ Schooling teaches us to rise above our animal instincts and appetites ${ }^{13}$ and restores us to humanity, but can even lift us up to God. ${ }^{14}$ However, learning should not be treated as an end in itself: it needs to be applied in real life, especially for the public good. ${ }^{15}$ Action is thus the second essential path to develop our humanity and receive eternal reward in the afterlife. ${ }^{16}$ The most useful discipline in this context is history, which provides us with examples of what to imitate and what to avoid. The study of history furthermore reveals what it means to be human, which is essential knowledge both for individuals to lead a prudent life and for rulers to conduct public affairs. ${ }^{17}$ But

11 Cf. Colish, The Mime of God, 13-16, and Noreña, Juan Luis Vives, 238-249.

12 Compare for instance Erasmus, De pueris statim ac liberaliter instituendis (quoted from Opera omnia Desiderii Erasmi Roterodami recognita et adnotatione critica instructa notisque illustrata I 2, ed. J. Margolin, Amsterdam: North-Holland Publishing Company, 1971, 1-78), 31: "homines, mihi crede, non nascuntur, sed finguntur", and 24: "non sit homo, qui literarum expers est". Vives himself is even more specific in De initiis, sectis et laudibus philosophiae: "cum sine ceteris rebus homo equidem sit semper, absque philosophia vero fera sit, non homo" (quoted from the ed./trans. by C. Matheeussen \& J. Roberts, in: Juan Luis Vives, Early Writings, ed. by C. Matheeussen - Ch. Fantazzi - E. George (Selected Works of J. L. Vives; 1), Leiden/New York/København/Köln: Brill, 1987, 54). See also I. Bejczy, 'Der christliche Humanismus des Juan Luis Vives', Archiv für Kulturgeschichte 84, 2002, 93-112 (esp. 96-101).

${ }^{13}$ See for instance the concluding section of the dialogue Prima salutatio in Vives, Linguae Latinae Exercitatio I 286 ed. Mayans.

${ }^{14}$ Vives, De disciplinis vi 5 ed. Mayans: "Cogitanti mihi nihil esse in vita vel pulchrius vel praestabilius cultu ingeniorum, quae disciplinae nominantur, qui nos a ferarum ritu et more separat, humanitati restituit, et ad Deum extollit ipsum."

15 See A. Buck, 'Juan Luis Vives' Konzeption des humanistischen Gelehrten', in: A. Buck (ed.), Juan Luis Vives. Arbeitsgespräch in der Herzog August Bibliothek Wolfenbüttel vom 6. bis 8. November 1980 (Wolfenbütteler Abhandlungen zur Renaissanceforschung; 3), Hamburg: Ernst Hauswedell, 1981, 11-21, and V. del Nero,' The De disciplinis as a Model of a Humanistic Text', in: Ch. Fantazzi (ed.), A Companion to Juan Luis Vives, 177-226 (esp. 220-221).

${ }^{16}$ Vives, De disciplinis vi 423-424 ed. Mayans: "Hic est ergo studiorum omnium fructus, hic scopus, ut quaesitis artibus vitae profuturis, eas in bonum publicum exerceamus, unde merces immortalis consequitur (...) infinitum quidem ex se est studium quodcunque, sed aliqua tamen eius parte incipere debemus illud ad aliorum commoditates ac emolumenta deducere."

17 Vives's concept of history is discussed in detail in J.A. Fernández-Santamaría, 'The Foundations of Vives' Social and Political Thought', in: A. Mestre (ed.), Ioannis Lodovici 
the greatest knowledge, which makes all human knowledge seem "mud and mere stupidity", is the knowledge of Christ, whose example teaches us most perfectly how to live our lives. ${ }^{18}$

Vives ascribes the fact that not everyone acts virtuously all the time to the free will, which for him is "the faculty or power of the soul to seek what is good and turn away from what is evil under the guidance of reason." ${ }^{19}$ Reason will always advise "love, harmony, peace, justice, moderation, in short: every kind of virtue and goodness", and will never suggest evil. ${ }^{20}$ However, it is the will (and not reason) which commands our actions, and this will is free because reason is its adviser and teacher, but not its mistress. ${ }^{21}$ In his De concordia et discordia, Vives indicates that the will may choose to deviate from the counsel of reason, but only at the loss of humanity and a return to the animal state, or even less. ${ }^{22}$ His analysis in De anima et vita, on the other hand, seems to imply that the will cannot act against reason, in the sense that it has no choice in being attracted by what is good and being repelled by what is evil, but can decide not to act upon this knowledge. ${ }^{23}$

Vivis Valentini Opera Omnia. I: Volumen introductorio, Valencia: Edicions Alfons el Magnànim, 1992, 255-261; and I. Bejczy, 'Historia praestat omnibus disciplinis: Juan Luis Vives on History and Historical Study', Renaissance Studies 17/1, 2003, 69-83.

${ }^{18}$ See chapter 10, entitled De Christo, in: Vives, Introductio ad sapientiam. The quoted passage is found in I 23 ed. Mayans: "Humana omnis sapientia, si cum religione Christiana conferatur, caenum est et mera stultitia." See also Vives, Introductio ad sapientiam I 30 ed. Mayans: "Documenti huius solidum et verissimum exemplar, oculis nostris ad imitationem propositum, sunt Christi actiones. Venit enim Dei filius, non ut verbis modo, sed exemplo vitae suae rectam nos doceret vivendi rationem ut illustratis sole illo suo animis nostris, aperte qualis quaeque res esset cerneremus."

19 Vives, De anima et vita III 382 ed. Mayans: "est igitur voluntas, Facultas, seu vis animi, qua bonum expetimus, malum aversamur, duce ratione".

${ }^{20}$ Vives, De concordia et discordia v 196 ed. Mayans: "[Deus] addidit rationem ducem et consultricem operum, quae nunquam ad discordiam aut odium, semper ad amorem, concordiam, quietem, iustitiam, aequitatem, omne denique virtutis et bonitatis genus, voluntatem adhortatur, et instigat." See also Vives, De anima et vita III 355 ed. Mayans: "Ratio data est homini ad inquirendum bonum ut id voluntas amplectatur."

${ }^{21}$ Vives, De anima et vita $1 \mathrm{II} 382 \mathrm{ed}$. Mayans: "voluntas quidem ipsa, domina est omnium et imperatrix, sed per se nihil habet lucis, illuminatur a mente, hoc est, a ratione ac iudicio, quae apposita est illi velut consultrix ductrixque (...) magistra est igitur, et praeceptrix voluntatis, ratio, non domina."

${ }^{22}$ Vives, De concordia et discordia v 196 ed. Mayans: "nec potest ab huius [i.e. rationis] consiliis voluntas discedere, nisi prius humanam dignitatem exuerit, et in feram transierit, aut fera etiam peius". For Vives's De concordia et discordia, see C. Curtis, 'The Social and Political Thought of Juan Luis Vives: Concord and Counsel in the Christian Commonwealth', in: Fantazzi (ed.), A Companion to Juan Luis Vives, 151-163.

${ }^{23}$ Cf. Casini, Juan Luis Vives' Conception of Freedom of the Will. 


\section{MAN'S SOCIALITY}

The passage in Vives's Fabula de homine in which the actor appears on stage as himself reveals that Vives sees man as a primarily political and social being:

The curtain was raised and he returned a man, prudent, just, sociable, human, kindly and companionable. He frequented cities with other men; he ruled and was ruled in turn. With others he attended to matters of public interest and welfare, and, in a word, was in no way either uncivil or unsocial. ${ }^{24}$

This conviction is repeated in several later works, such as De initiis, sectis et laudibus philosophiae (in which Vives states that mortals only become truly human when they follow their natural inclination to organize themselves in a society regulated by common laws) ${ }^{25}$ or his Aedes legum (in which he indicates that nothing is more pleasing to God than human society, in which men and women are bound by law and which is ruled by justice, peace, hospitality, and other virtues). ${ }^{26}$ In the first book of his De concordia et discordia, he furthermore argues that a life spent alone is like death, and that God created man, contrary to animals, as weak and

${ }^{24}$ Vives, Fabula de homine IV 5 ed. Mayans: "velo diducto redibat mox prudens, iustus, socius, humanus, benignus, comes homo, frequentabat cum aliis civitates, vicissim imperabat et parebat imperio, quae ad publicos attinebant usus atque utilitates ipse cum aliis curabat, denique nullus non erat civilis sociusque." The English translation is quoted from Colish, The Mime of God, 5-6 (whose translation of this passage I prefer over the one by Nancy Lenkeith in The Renaissance Philosophy of Man). A general discussion of Renaissance views on the origins of society (and their reliance on Aristotle and Cicero) is found in V. Syros, 'Founders and Kings Versus Orators: Medieval and Early Modern Views on the Origins of Social Life', Viator 42/1, 2011, 383-408.

${ }^{25}$ Vives, De initiis, sectis et laudibus philosophiae, 18-19: "Hinc prima olim haec sapientia credita est qua, ut Horatius canit, molliti ac manesuefacti homines, cicuriores ex efferatissimis redditi, in sententiam musici bene monentis iere, ut, relictis specubus casisque quas seorsum singuli inhabitabant, coirent in conventus, iura communia civitatum, et in societate (ad quam sua sponte humanum ingenium fertur) viverent, veri iam homines facti."

${ }^{26}$ Vives, Aedes legum, 16 (quoted from the critical edition by Constantinus Matheeussen in Juan Luis Vives, Praefatio in leges Ciceronis et Aedes legum [Bibliotheca Scriptorum Graecorum et Romanorum Teubneriana], Leipzig: Teubner, 1984): “Cum in humanam societatem venissem a deo nostro imperatore (sumus etenim homines hominum causa creati 'neque nobis nati solis', ut aiebat Plato), pedentim in locum munitissimum pariter et amoenissimum quendam me contuli, quo nihil in terris affirmabant illi principi deo gratius atque iucundius. Civitatem eam appellabant, ubi concilia coetusque hominum iure sociati, ubi iustitia et pax, ubi humanitas, fides, hospitalitas et aliae quae in hominibus hominum causa sunt virtutes." The reference is to Plato, Epist. IX 358a, perhaps through Cic., De Fin. II 45 or Cic., De Off. I 22. 
defenseless beings, so that they would be united by mutual dependency. ${ }^{27}$ To this end, human beings are endowed with memory, so that they would remember the assistance they received from their parents, neighbours and teachers. Memory also contributes to the conservation of society, especially as we are reminded that all humans share the same condition and that we need to act for the common good, if we do not want to violate the laws of nature. ${ }^{28}$ In other words, the fact that man is naturally disposed to living in society and shares in a common human nature, has repercussions for his duties in life. It is, for instance, a moral and practical obligation to care for members of society who are unable to fend for themselves. This is the topic of Vives's De subventione pauperum, in which he not only calls upon the individual, but also on state authorities to care for the poor. ${ }^{29}$ The treatise is divided into two books, of which the first provides the philosophical and theological background (offering Vives's typical blend of pagan and Christian thought) for the specific programme of poor relief detailed in the second. In the opening chapters of the first book, Vives sketches the development of mankind. At the time of creation, man was the greatest being in the sublunar world, with a strong body and a mind developed to contemplate divine matters. However, he would not content himself with the position assigned by God and aspired to divinity itself, resulting in the destruction of his paradisiacal state:

While he tried to be more than the angels, he became less than man (...) his mind was blunted, his reason obscured; pride, envy, hatred, brutality, multiform desires and all other passions were roused up like tempests from the

27 Vives, De concordia et discordia v 200 ed. Mayans: "ea [i.e., solitudo] instar sit mortis" \& 198: "[Homo est] animal inerme ac proinde innoxium, ut intelligat qualem se debet inter homines praebere, nam a noxiis feriis societas eum et consensus aliorum hominum defendet, ut mutuo sint alii aliis auxilio."

${ }^{28}$ Vives, De concordia et discordia v 196-197 ed. Mayans: "homo vero et parentes, et propinquos, educatores, paedagogos, institutores recordatur, omnes denique, qui illi quacunque ratione ac modo profuerunt (...) totum hominum genus haud aliter aspicit quam socios, ut commonefactione similitudinis et communis naturae, natum se ad omnium usus esse non ignoret, ne quam praetermittat benefaciendi aliis occasionem, non nescius praetermitti id non posse sine violatione legum naturae." See also Vives, Introductio ad sapientiam I 33 ed. Mayans: "Fortuna et casus humani sunt omnibus communes, unicuique minantur, unicuique impendent. Hoc amore hominibus debito, nihil existimato posse te facere aptius et congruentius, quam si maximum bonum, hoc est, virtutem, eis procuraveris; si studueris, ut omnes si potes, utique quam plurimos reddas bonos."

${ }^{29}$ For De subventione pauperum and its influence, see especially H.C.M. Michielse - R. van Krieken, 'Policing the Poor: J. L. Vives and the Sixteenth-Century Origins of Modern Social Administration', The Social Service Review 64/1, 1990, 1-21; Ch. Fantazzi, 'Vives and the Emarginati', in: Fantazzi (ed.), A Companion to Juan Luis Vives, 94-111; and the introduction to J.L. Vives, De subventione pauperum sive de humanis necessitatibus libri II, ed. by C. Matheeussen - Ch. Fantazzi (Selected Works of J. L. Vives; 4), Leiden/Boston: Brill, 2002 . 
waves driven by the south wind (...) it seemed that there was nothing, either interior or exterior, that did not conspire to the destruction of the body. ${ }^{30}$

In this weak state, even the strongest and cleverest of men needed the help of others. Love and friendship developed because man learned the advantages of mutual service, both within the confines of one's own household and outside. Like-minded people thus founded communities, in which labour was divided. At the same time, however, need was created as not everyone had enough to sustain themselves, either through abuse by others or because of misfortune. Despite the fact that this vulnerability of man is a just punishment for his pride at the time of the Fall, God nevertheless took pity and instilled the need to help one another in the form of charity, which implies providing assistance on three different levels:

We must do good by spiritual means, like prayers, advice, prudence, rules of life; by material means, like physical presence, verbal intercession, strength, work, procuratorship; and in external things, like status, authority, influence, friendships, money, under which are included things procured by money. In whatever way you can, you must help and be of use to those who are in need. ${ }^{31}$

It is not only considered to be inhuman and against nature not to help the needy, it is also in our interest to do so, since we might need help ourselves one day and because our society would become unhinged if everyone would seek their own advantage. Although we might be reluctant to help, especially if we doubt whether we will receive suitable gratitude, we still need to rise to the occasion and do the right thing. Referring to Seneca's De beneficiis - of which he quotes an extensive passage $^{32}-$ Vives argues that virtue consists of doing good without the certainty of any return. Besides, everything that was given to us by God was not given for

30 Vives, De subventione pauperum, 6-9: "Dum plus esse conatur quam angelus, minus fuit quam homo (...) Retusa est mens, obscurata ratio; superbia, invidia, odium, saevitia, cupiditates multiformes et perturbationes reliquae ceu tempestates quaedam excitatae undis austro percitis (...) ut nihil nec intrarium sit nec extrarium quod non in corporis perniciem videatur conspirasse."

31 Vives, De subventione pauperum, 20-21: "Benefaciendum iis quae sunt in animo: votis, consilio, prudentia, praeceptis vitae; et quae in corpore: praesentia corporum, verbis, viribus, labore, procuratione; et externis: dignitate, auctoritate, gratia, amicitiis, pecunia (sub qua ea sint mihi comprehensa quae pecunia comparantur). Quacumque re quis possit, iuvet et prosit illis qui indigent."

32 Vives, De subventione pauperum, 42-44. 
ourselves but for the sake of others, so we have the obligation to share, or we will otherwise not be able to avoid punishment, either by human or divine law. ${ }^{33}$

\section{HUMAN RESPONSIBILITY}

In his commentary on what he considered to be the most important text of the whole philosophical corpus, namely Cicero's Somnium Scipionis, ${ }^{34}$ Vives argued that it is essential to "fulfill the responsibility of the human race" ${ }^{35}$ by being kind, benevolent, clement and charitable, in order to ascend to heaven after the death of our earthly bodies, which are nothing but "a cloak, a vessel, a repository, chains, a prison".$^{36}$ God has willed our heavenly souls to descend on Earth and assume these burdensome bodies for a reason, namely to act as the "nurturers and guardians of the Earth" ${ }^{37}$ Whatever the precise task may be which is set to us on the basis of our individual talents and skills, we do not have the right to refuse it, not even by freeing our soul from its bodily prison by committing suicide. ${ }^{8}$ What our task in

${ }^{33}$ Vives, De subventione pauperum, 66-63: "Quisquis quod superest necessariis naturae usibus non egenis impartit, fur est, et, si non humanis legibus (quamquam his etiam nonnullis), certe divinis punitur."

${ }^{34}$ Juan Luis Vives, Somnium et Vigilia in Somnium Scipionis (Commentary on the Dream of Scipio), ed. with an intr., trans. and notes by E.V. George (The Library of Renaissance Humanism; 2), Greenwood, sC: Attic Press, 1989, 4: "Nullumque est in tota philosophia praestabilius opus atque divinius." For Vives's commentary of the Somnium Scipionis, see D. Verbeke, 'Entre philosophie et philologie: Le Vigilia in Somnium Scipionis (1520) de Juan Luis Vives', in: L. Boulègue (ed.), Commenter et philosopher à la Renaissance (Cahiers de philologie), Villeneuve d'Ascq: Presses Universitaires du Septentrion, forthcoming; and the literature mentioned there.

${ }^{35}$ Vives, Somnium et Vigilia in Somnium Scipionis, 146-147: "officio illo suo hominum generi a Deo commisso et mandato".

36 Vives, Somnium et Vigilia in Somnium Scipionis, 194-195: "Est enim corpus hominis seu amiculum, seu vas, seu receptaculum, seu vincula, seu carcer, seu quo alio appelari libet nomine."

37 Vives, Somnium et Vigilia in Somnium Scipionis, 202-205: "[Deus], qui animos in humana corpora sparsit atque consevit, ut essent qui terram illam vestram colerent ac tuerentur". See also 132-133: "Qui animi idcirco hinc ad terram delapsi sunt, definitoque unicuique et certo temporis curriculo in ea morantur, ut imperante Domino illo atque auctore huius universitatis excolant tueantur terram ipsam, nec obsolescere et situ squaloreque contegi patiantur (et contabescere)."

38 Vives, Somnium et Vigilia in Somnium Scipionis, 132-133: "Sive igitur missi sunt animi nostri in corpora, tamquam legati ad munus aliquod obeundum, sive tamquam milites ad custodiendum et praesidendum loco alicui, sive tamquam servi in vincula ergastuli coniecti et detrusi, manendum ibi est nec voluntario abeundum, nec fugiendum, neu perfringenda vincula, sed exspectandum quoad vel revoceris, vel a magistratu illo et legitima 
life is will be clear when we follow our conscience. We should not pay too much heed to the opinion of others, and certainly not "hang upon the hollow gossip or approval of the empty-headed rabble". Instead, we need to listen to the judge, peerless and penetrating, the ever-watchful arbiter, the truest and most scrupulous witness of all intentions and acts, namely the mind's conscience, bestowed by God, the very prince and creator of the universe. ${ }^{39}$

This is repeated in Vives's Introductio ad sapientiam, where we read that the voice of our conscience should have priority over the opinion of the mob, since we will never find peace - no matter what our material circumstances are - unless our conscience is clear. Conscience is compared to a 'wall of bronze' (an expression taken from Horace's Odes), which keeps us safe from life's dangers and cannot be breached..$^{40}$ This is exemplified in Vives's Pompeius Fugiens, a short speech written from the perspective of Pompey after having been defeated by Caesar at the battle of Pharsalus in $4.8 \mathrm{BC}$. Abandonded by all, Pompey realises that he is the victim of the fickleness of fortune: after having risen to the pinnacle of success, he has now fallen deeper than any other. And still, he is not completely without consolation because he knows that - even if everyone in the world would condemn

potestate emittaris exemptus, ne vel tamquam legatus (...) dum vitam per voluntariam corporis mortem quaeris, in aliam incidas mortem ipsius animi quamlibet immortalis. Sempiternus namque apud Orcum cruciatus, non is tibi magna videtur animi mors?" For Vives's reflections on suicide, see also his commentary on the first book of Augustine's De civitate Dei, now available in a modern edition by F.G. Pérez Durà and I.M.a Estellés González as the second volume of the Opera omnia Ioannis Lodovici Vivis Valentini, Valencia: Edicions Alfons el Magnànim, 1992.

${ }^{39}$ For this, and the next, quote see Vives, Somnium et Vigilia in Somnium Scipionis, 190-191: "non exspectare inanem inanis turbae sermunculum ac plausum (...) maximum habere se acremque iudicem, vigilantem arbitrum, verissimum et religiosissimum suorum omnium consiliorum atque factorum testem conscientiam mentis suae, quam ab Deo illo naturae principe atque opifice accepit." See also the closing paragraphs of Vives's commentary, where he iterates the point (210-211): "omnia tua in te uno sita esse duces, nec opes alias requires quam virtutes quae in te erunt, nec sermonem de te quemquam praeter illum quem recta tua loquetur conscientia".

${ }^{40}$ Vives, Introductio ad sapientiam I 45 ed. Mayans: "Pluris facias iudicium conscientiae tuae quam voces omnes ingentis multitudinis, quae imperita et stulta est: ignota temere ut probat, sic et damnat. Conscientia est, quae turbata maximos affert animo cruciatus; tranquilla maximam beatitudinem: cui nullae opes, nulla possunt regna comparari. (...) Conscientia verum et solidum et duraturum reddit testimonium plurimum in illo Dei iudicio valiturum, vitaeque huius magna est magistra. Et quemadmodum scite ille dixit, murus aheneus, quo et tuti agimus inter innumera vitae pericula, et securi: nec ullus est tantus terror, qui muro hoc septum commoveat; est enim mente defixus Deo, illique fidit uni, ac ei se novit peculiari esse curae cui scit parere universa." For 'murus aheneus', see Hor., Carm. III 3.65. 
his behaviour - he has acted according to his conscience and has made the best of his mortal nature:

In this sea of trouble, in this sad and wretched war, my lone consolation is my conscience, the witness of my soul, intentions, mind, reason, judgment and feeling, of my cause and my will. (...) And if, as truth and reason direct, we are required to pay a penalty only for our own guilty deeds, if nothing is demanded of a man who is good save a sanctified and unviolated will, a full intention to practice virtue and duty as far as possible, and a determination not to fail in directing any of his energy toward the honorable course, then I do not see what fault anyone can find in me. Whatever there was in my mortal nature I brought to fulfillment. ${ }^{41}$

Making the best of our mortal nature implies also that we do not give ourselves up to corporeal pleasures and earthly delights, but that we focus on the divine pursuits cultivated by our celestial souls: "justice, self-restraint, prudence, devotion to duty, knowledge and wisdom". ${ }^{42}$ A focus on the heavenly afterlife leads to the contemplation and practice of virtue in the present. ${ }^{43}$ In the context of Vives's commentary on the Somnium Scipionis, this virtue first and foremost takes the shape of serving one's country and society as a whole. The underlying conviction is - just as in De subventione pauperum - that we are not born for ourselves and that we are not wholly human unless we put the common good above our own well-being. If we do not do this, then we are at war with nature and we deserve to be driven outside society and to be denied human status. ${ }^{44}$

41 Vives, Pompeius Fugiens, 144-145; quoted from the edition/translation by E. George \& C. Matheeussen in: Vives, Early Writings (Selected Works of J. L. Vives; 1): "Ac me quidem in tantis meis malis unica conscientia testis animi mei, consilii, mentis, rationis, iudicii, sententiae, causae, voluntatis meae, in hoc tristi et miserabili bello, me consolatur (...) Et si, ut veritas ratioque praescribit, nihil aliud est praestandum a nobis in vita praeter culpam, nihil aliud exigitur a bono viro quam integra et sancta voluntas, quam consilium virtutis atque officii, quoad fieri potest plenum, quam ne ipse pro sua virili honesto dedit, quid in me reprehendere quisquam possit non video. Ego quicquid in mortalitate mea fuit, effeci."

${ }^{42}$ Vives, Somnium et Vigilia in Somnium Scipionis, 166-167: "iustitia, continentia, prudentia, pietas, scientia, sapientia, quae iure divina studia nuncupantur".

${ }^{43}$ Vives, Somnium et Vigilia in Somnium Scipionis, 191-194.

44 Vives, Somnium et Vigilia in Somnium Scipionis, 204-205: "Isque contra naturam pugnare armaque adversus humanitatem sumpsisse videtur, qui suae utilitatis gratia communem utilitatem negligit ac violat, societatemque humanam dissolvit, dignus qui tamquam hostis ex illa pellatur, eaque ipsi negetur humanitas quam aliis ipse denegavit." 


\section{PHILOSOPHY AS A GUIDE FOR COMMUNAL LIFE}

Civilised society is regulated by laws. In his Praelectio in Leges Ciceronis, Vives specifies that there is natural law, divine law, national law, civil law, and military law. ${ }^{45}$ He refers to the first book of Aristotle's Republic for the first and specifies that it is the kind which is inscribed in the heart of all human beings from birth. ${ }^{46}$ In other words, natural law is general and immutable, since it stems from the invariable nature of all humans, who are all born with a need to venerate God, a desire for communal life, a respect for superiors, elders, and wise men, and a knowledge of right and wrong. ${ }^{47}$ This natural law is the source and origin of all other kinds of laws and has two central commands which are not open for choice or debate, namely to worship God and to protect human society. ${ }^{48}$ However, Vives still admits that we need a guide to understand what the nature of man is. This leading role is reserved for philosophy, which - in imitation of Cicero's Tusculanae Disputationes - is called the "guide in life, she who searches for virtues and drives out vices". ${ }^{49}$ Philosophy is valuable to all: it teaches the poor man to support his poverty, the rich man to use his riches justly, the happy man to control his happiness properly, and the unhappy one to tolerate his unhappiness better. ${ }^{50}$ The philosopher also has the obligation to share his knowledge with others and to focus on practical matters which are beneficial for the common good, and Vives resents the philosophers who refuse to act this way:

There were many philosophers who rejected the care for family or public matters and devoted themselves so much to the speculation and contemplation of matters that they withdrew into solitude, far away from human contact, and

${ }^{45}$ For a brief discussion of Vives's philosophy of law, see C. Matheeussen, 'Das rechtsphilosophische Frühwerk des Vives', in: A. Buck (ed.), Juan Luis Vives, Arbeitsgespräch in der Herzog August Bibliothek Wolfenbüttel vom 6. bis 8. November 1980 (Wolfenbütteler Abhandlungen zur Renaissanceforschung; 3), Hamburg: Ernst Hauswedell, 1981, 93-106.

${ }^{46}$ Vives, In leges Ciceronis praefatio, 2 (quoted from the critical edition by Constantinus Matheeussen in Juan Luis Vives, Praefatio in leges Ciceronis et Aedes legum [Bibliotheca scriptorum Graecorum et Romanorum Teubneriana], Leipzig: Teubner, 1984): "Ius naturale (...) est quod habent omnes scriptum in cordibus suis eduxeruntque secum ex matris utero." The reference is, in fact, to Eth. Nic. v 7, 1134b.

47 Vives, In leges Ciceronis praefatio, 2-3.

48 Vives, In leges Ciceronis praefatio, 3: "Nullum opinor vestrum dubitare quin leges divinae, gentiles, civiles ac militares ab ipsa lege naturae profectae sint (...) Ideo namque videmus de lege naturae (utpote venerando deo tuendaque hominum societate) neminem aut consulere aut eligere (...) De fine enim, ut Aristoteles inquit, rebusque certis nulla est neque electio neque deliberatio neque consilium." The reference is to Eth. Nic. III 3, 1112b.

${ }^{49}$ Vives, In leges Ciceronis praefatio, 7: "vitae dux, virtutum indagatrix expultrixque vitiorum". Cp. Cic., Tusc. v 5: "O vitae philosophia dux, o virtutis indagatrix expultrixque vitiorum!"

${ }^{50}$ del Nero, The De Disciplinis as a Model, 222-223. 
spent sleepless nights and whole days without food, forgetting themselves, as if they were pure spirits not tied up with a body. Apparently living another life while they existed here, they tried to study the natures of things with undefatigable effort. In my opinion, this is not at all an excellent endeavour, but unworthy of this immortal soul of ours and not so much useful for others as it is for themselves. ${ }^{51}$

The belief supporting this approach to philosophy is the same as the one expressed in De subventione pauperum and the commentary on the Somnium Scipionis, namely that intellect and wisdom are bestowed upon us by God for the good of all, in the same manner as wordly goods are given to us, not to be used for our own self-interest, but to manage them wisely and distribute them for the common good. The prime example of such an engaged philosophy is - according to Vives - found in Cicero himself, who not only wrote many volumes of 'practical philosophy', but also sacrificed himself - despite many domestic sorrows - to the care and protection of the state. This image of Cicero as an almost ideal man worthy of imitation because he made the most of his human nature by devoting himself to study, by sharing his knowledge with his fellow human beings, and by sacrificing himself for the preservation of the state and the common good, is quite common in Renaissance humanism. Especially in the transalpine humanist tradition, Cicero was a guiding light, not only in stylistic or grammatical matters, but also in life itself, which was both cause and effect of the enormous popularity of his writings. ${ }^{52}$

\section{CONCLUSION}

This relatively short overview of statements of Vives concerning human nature and the subsequent moral responsibilities illustrates his "constant effort to understand human nature not as a metaphysician but as a moralist and a pedagogue". ${ }^{53}$ Although Vives's thought has been described in the past as "unsystematic, com-

51 Vives, In leges Ciceronis praefatio, 8: "Multi fuerunt philosophi qui, reiecta rei familiaris et publicae cura, adeo rerum speculationi contemplationique sese dediderunt, ut secedentes in solitudinem, ab hominum congressu semoti, noctes insomnes ducentes, dies totos sine nutrimento, obliti sui, quasi meri spiritus in corpore corpori non commixti, velut hic exsistentes aliam vitam viventes, indefesso studio rerum naturas investigare conati sunt. Ne illa praestantissima quidem res est meo iudicio et hac nostra immortali anima digna, sed non tam aliis quam sibi ipsi utilis."

52 D. Baker-Smith, 'Juan Vives and the Somnium Scipionis', in: R.R. Bolgar (ed.), Classical Influences on European Culture A.D. 150o-170o. Proceedings of an international conference held at King's College, Cambridge April 1974, Cambridge: Cambridge University Press, 1976, 239-244 (here 239).

${ }^{53}$ Casini, Juan Luis Vives' Conception of Freedom of the Will, 398. 
plex, and sometimes even nebulous and contradictory", ${ }^{54}$ the central tenets of his concept of man are clear. Man's fragile nature indicates that God created human beings defenseless and weak, so that they would be united by mutual assistance and be naturally disposed to organise themselves in civilised communities. We are furthermore placed on Earth for a reason, namely, to guard the sublunar world; and we cannot flee from this task without being punished by the loss of our humanity and/or by human or divine law. Reason (which is developed by education and study), conscience and - above all - our love of God and the example and doctrine of Christ ${ }^{55}$ guide us to live our lives according to God's will. Morality is thus presented as the acme of human perfection: ${ }^{56}$ only he who lives a virtuous life as a good Christian, devoted to peace, harmony, charity, and good-will, can become truly and fully human..$^{57}$

Vives's analysis of the human condition is thus similar to Erasmus's Philosophia Christi, of which he is sometimes said to represent the intellectual side (whereas Erasmus is seen as the literary variant)..$^{8}$ Erasmus equally believes that reason shows us the path of moral virtue and that education brings the rational element in human beings to fruition, thus instilling goodness and kindness in each individual. The difference between Vives and Erasmus lies in the elaboration. Erasmus's teachings sometimes seem too idealistic and unobtainable because he "served the pure idea [...] of a moral humanity" ${ }_{59}$ rather than the practical application of it. Vives, on the other hand, favours education as well as action to develop our humanity, and does not shy away from providing detailed advice on how to behave as responsible and valuable members of society, thus realizing God's plan by fulfilling the potential and the obligation instilled in our human nature.

54 Noreña, Juan Luis Vives, 123.

55 Vives, Introductio ad sapientiam I 17 ed. Mayans: "Nec aliud conatur pietas Christiana, quam ut serenitas humanos animos exhilaret et tranquillitate animorum compositisque affectionibus simus Deo, angelis quam simillimi. Remedia his morbis, vel ex rebus ac nobis ipsis, vel ex Deo, vel ex Christi lege ac vita petuntur."

${ }^{56}$ Noreña, Juan Luis Vives, 200.

57 Vives, De pacificatione v 406 ed. Mayans: "Satis arbitror, quum ab aliis permultis, tum a me ipso nuper quatuor esse voluminibus declaratum, neminem non solum christianum appellari posse, id est, perfectum et consummatum hominem, sed nec hominem quidem, qui paci, concordiae, caritati, benevolentiae, quantum ab eo praestari possit, non studeat: huc a natura nos et corporum et animorum nostrorum impelli atque incitari, huc adduci a Magistro divinae sapientiae ac veritatis, ab interprete naturae, immo illius Principe atque Auctore."

58 Bejczy, Der christliche Humanismus des Juan Luis Vives, 111. For the influence of Erasmus on Vives, and their differences, see Noreña, Juan Luis Vives, 123-147.

59 F. Caspari, 'Erasmus and the Social Functions of Christian Humanism', Journal of the History of Ideas 8/1, 1947, 78-106 (here 93). 